\title{
Museomics Clarifies the
} Classification of Aloidendron (Asphodelaceae), the Iconic African
Tree Aloes

\author{
Panagiota Malakasi, Sidonie Bellot, Richard Dee and Olwen M. Grace* \\ Comparative Plant \& Fungal Biology, Royal Botanic Gardens, Kew, Surrey, United Kingdom
}

Arborescent succulent plants are regarded as keystone and indicator species in desert ecosystems due to their large stature and long lifespans. Tree aloes, the genus Aloidendron, are icons of the southern African deserts yet have proved elusive subjects due to the difficulty of obtaining material of known provenance for comparative study. Consequently, evolutionary relationships among representatives of the unusual arborescent life form have remained unclear until now. We used a museomics approach to overcome this challenge. Chloroplast genomes of six Aloidendron species and 12 other members of Asphodelaceae were sequenced from modern living collections and herbarium specimens, including the type specimens of all but two Aloidendron species, the earliest of which was collected 130 years ago. Maximum-likelihood trees estimated from full chloroplast genomes and the nuclear internal transcribed spacer (ITS) region show that Aloidendron sabaeum, from the Arabian Peninsula, is nested within Aloe while the Madagascar endemic Aloestrela suzannae is most closely related to the Somalian Aloidendron eminens. We observed phylogenetic conflicts between the plastid and nuclear topologies, which may be indicative of recurrent hybridisation or incomplete lineage sorting events in Aloe and in Aloidendron. Comparing species ecology in the context provided by our phylogeny suggests that habitat preference to either xeric deserts or humid forests/thickets evolved repeatedly in Aloidendron. Our findings demonstrate the value of botanical collections for the study and classification of taxonomically challenging succulent plants.

This article was submitted to Plant Systematics and Evolution, a section of the journal

Frontiers in Plant Science

Received: 20 June 2019 Accepted: 04 September 2019 Published: 15 October 2019

Citation:

Malakasi P, Bellot S, Dee R and Grace OM (2019) Museomics Clarifies the Classification of Aloidendron (Asphodelaceae), the Iconic African Tree Aloes.

Front. Plant Sci. 10:1227. doi: 10.3389/fp/s.2019.01227
Keywords: aloe, botanic garden, evolution, herbarium, phylogenomic analysis, systematics

\section{INTRODUCTION}

The presence of water-storing tissues in plants is a common adaptation to drought that has evolved multiple times. The condition, known as succulence, is most commonly associated with two categories in Raunkier's (Raunkier, 1934) classification of plant life forms: nanophanerophytes (having woody stems, persisting for several years, and having buds below $3 \mathrm{~m}$ ) and diminutive chamerophytes (having herbaceous or woody stems, persisting for several years, and having buds on or near soil level and not above $50 \mathrm{~cm}$ ). Relatively few succulent plants are arborescent phanerophytes (having woody stems, persisting for several years, having buds above $3 \mathrm{~m}$ ) (Raunkier, 1934), and tree-like succulents are therefore conspicuous in the arid landscape. They are sometimes regarded as keystone and indicator species for the habitats in which they occur 
due to their large stature and long lifespans. Examples include the saguaro cactus [Carnegiea gigantea (Engelm.) Britton \& Rose, Cactaceae] in the Sonoran desert, the candelabra tree [Euphorbia ingens E. Mey. (Euphorbiaceae)] in the subtropical drylands of southern Africa (Van Der Linde et al., 2012), and the quiver tree [Aloidendron dichotomum (A. Berger) Klopper \& Gideon F.Sm. (Asphodelaceae subf. Alooideae)]. The latter, an icon of the Namib desert, has been proposed as an indicator for species migration associated with anthropogenic climate change (Foden et al., 2007; Jack et al., 2016). Here, we focus on the genus Aloidendron. Aloidendron comprises seven species known colloquially as tree aloes, due to their distinctive arborescent habit with dichotomous branching and compressed terminal rosettes of succulent leaves (Figure 1), and its close relationship to the ( $\sim 500$ species $)$ of the leafsucculent genus Aloe. Two other iconic arborescent aloes are sometimes included in a broad concept of tree aloes: the dichotomously branched Cape endemic Kumara plicatilis (L.) G.D. Rowley and the (usually) unbranched species Aloestrela suzannae (Decary) Gideon F.Sm., which is restricted to the arid spiny thicket of southern Madagascar.

All species of Aloidendron are confined to Namibia, South Africa and Mozambique, with two exceptions: Aloidendron eminens (Reynolds \& P.R.O. Bally) Klopper \& Gideon F.Sm., endemic to Somalia, and Aloidendron sabaeum (Schweinf.) Boatwr. \& J.C. Manning, only found in the Arabian Peninsula (Figure 1). Until now, it has not been clear whether the disjunct distribution of Aloidendron in the southern and northern native range limits of the closely related genus Aloe was due to a similar biogeographic history as the one inferred for Aloe, which underwent a series of radiations from a common ancestor in southern Africa from $~ 15$ Mya, before finally reaching the Arabian Peninsula $\sim 5$ Mya (Grace et al., 2015).

Aloidendron species occur in either arid or humid thicket/ forest habitats. Three closely related southern African desert species, A. dichotomum (Masson) Klopper \& Gideon F.Sm., Aloidendron ramosissimum (Pillans) Klopper \& Gideon F.Sm. and Aloidendron pillansii (L. Guthrie) Klopper \& Gideon F.Sm., occur on rocky slopes in the arid Northern Cape province of South Africa and in southern Namibia to approximately 1,500 $\mathrm{m}$ (van Wyk and Smith, 2001). A fourth arid species, A. sabaeum, is widespread along the escarpment of the Arabian Peninsula, extending from the Aseer Province in southern Saudi Arabia to Hardramaut in eastern Yemen, and occurs at a range of altitudes from 150 to 2,000 m (Reynolds, 1966; Carter et al., 2011). In southern Africa, the thicket- and forest-dwelling species occur on sandy soils at sea level or low altitudes in the Eastern Cape and KwaZulu-Natal provinces of eastern South Africa, extending northwards into Eswatini and Mozambique. These include Aloidendron barberae (Dyer) Klopper \& Gideon F.Sm. (coastal thicket, grassland) and Aloidendron tongaensis (van Jaarsv.) Klopper \& Gideon F.Sm. (sand forest). A third forest species, A. eminens, is known only from a narrow distribution in Erigavo District, Somalia, where it occurs on forested slopes at altitudes of 1,550-1,830 m (Carter et al., 2011) (Figure 1).
The evolutionary relationships underlying the fragmented distribution of arborescent aloes have hitherto remained unconsidered in a phylogenetic context. One of the reasons for this knowledge gap is that long-lived succulent phanerophytes such as Aloidendron may reach flowering maturity only after a decade or more and/or rarely flower in cultivation, posing a challenge to scholars who are reliant on specimens verified with flowering material for research. We used a museomics approach to overcome this challenge. Museum collections globally have doubled since 1960 (Goodwin et al., 2015) and represent a rich source of plant material for research. Advances in -omics technologies now allow the exploitation of old, poorly preserved and fragmentary plant material to be included in molecular studies of evolution, systematics and taxonomy. Whole chloroplast genomes of preserved herbarium specimens and living plants were sequenced to illuminate phylogenetic relationships among tree aloes. The inclusion of type specimens and verified living collections of Aloidendron and Aloe allowed us to produce a phylogenomic hypothesis with which we could assess the taxonomic placement of all seven Aloidendron species and A. suzannae.

\section{METHODS}

\section{Sampling, DNA Extraction and Library Preparation}

Plant material for investigation was obtained from herbarium specimens at the Herbarium at Kew (K) and accessions of known provenance grown in curated living collections (Table 1). Vouchers of ex hort material were deposited at the Herbarium at Kew (K); the H.G.W.J. Schweickerdt Herbarium at the University of Pretoria (PRU), South Africa; and the herbarium of the Sukkulenten-Sammlung in Zurich, Switzerland (Table 1). The sampling included 26 species in total: six out of the seven species of Aloidendron, 10 species of Aloe representing the major clades and geographical distribution, the monotypic A. suzannae and Bulbine frutescens (L.) Willd. as the outgroup for the phylogeny.

To extract total genomic DNA from living plants, $\sim 0.2 \mathrm{~g}$ of silica-dried leaf tissue was powdered with metallic beads in a Qiagen TissueLyser (Hilden, Germany). DNA was then extracted and purified with the Qiagen DNeasy plant DNA kit (Manchester, UK) according to the manufacturer's protocol. We used a different method for old herbarium specimens, which are expected to contain highly degraded DNA. First, $\sim 0.1 \mathrm{~g}$ of herbarium material was finely ground in a mortar, using liquid nitrogen. Genomic DNA was then extracted from the resulting powder using a modified $2 \times$ CTAB method (Doyle and Doyle, 1987) where the DNA was precipitated with isopropanol for 2 weeks at $-80^{\circ} \mathrm{C}$. The extracted DNA was cleaned with AMPure XP Beckman Coulter beads, using a 1:1 beads-to-DNA ratio in order to maximise the retrieval of small DNA fragments. The DNA concentration was quantified using the QuantiFluor dsDNA System (Promega) on a Quantus fluorometer (Invitrogen, $\mathrm{UK}$ ), and fragment size was assessed by electrophoresis in a $1 \%$ agarose gel. 

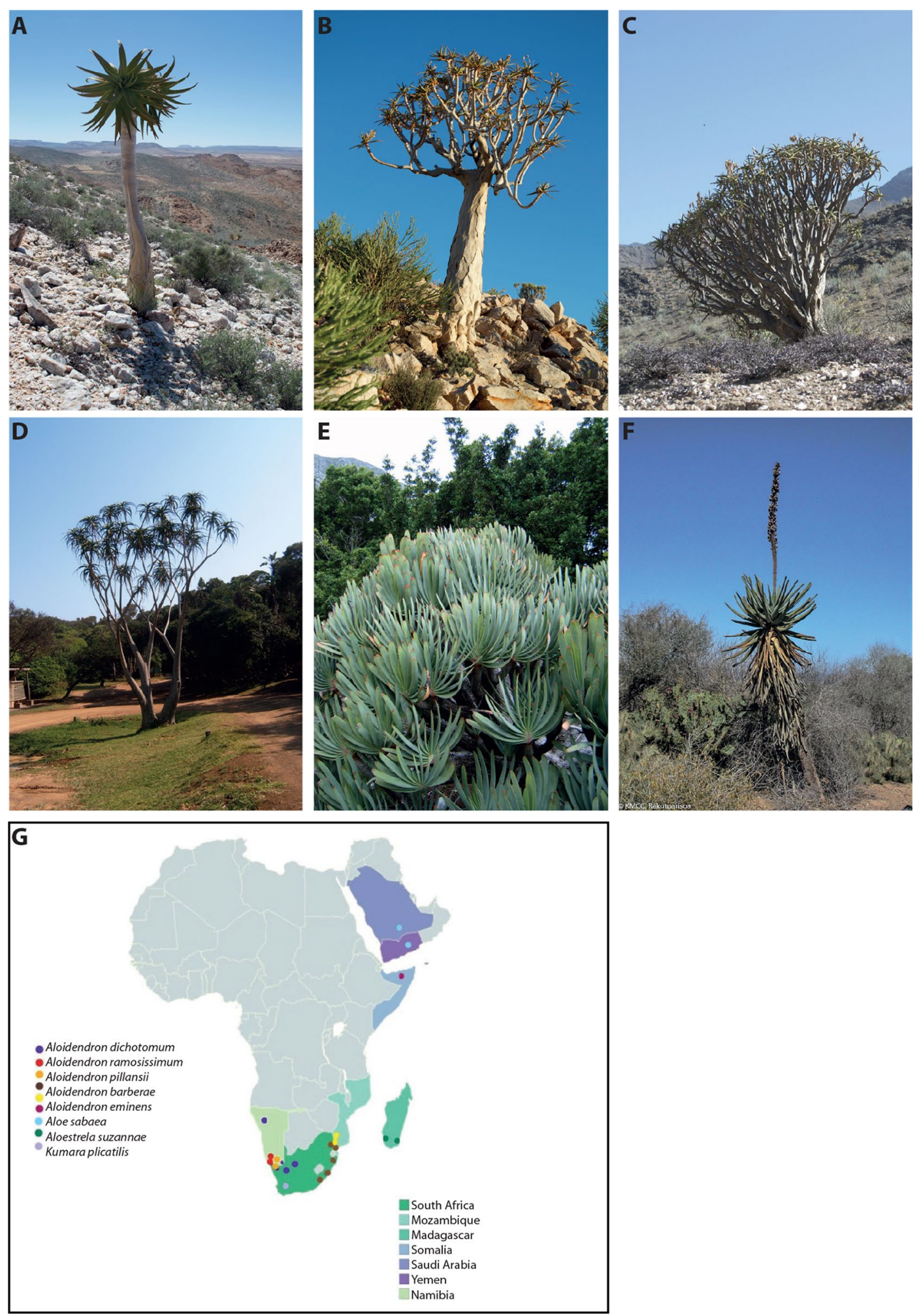

FIGURE 1 | The genus Aloidendron comprises seven species characterised by an arborescent habit and succulent leaves (photographs O.M. Grace unless otherwise stated). Three iconic species are endemic to the southern African deserts (A) Aloidendron pillansii, (B) Aloidendron dichotomum and (C) Aloidendron ramosissimum, while (D) Aloidendron barberae in KwaZulu-Natal is one of three species found in humid coastal thicket and forest in southern Africa, along with Aloidendron eminens (not shown) in Somalia and the Arabian Peninsula. Two iconic taxa sometimes regarded as tree aloes include (E) Kumara plicatilis, a distinctive Cape endemic and (F) Aloestrela suzannae, a distinctive unbranched arborescent species endemic to the spiny forest of Madagascar (photograph R.S. Rakotoarisoa). (G) Distribution map of the seven species of tree aloes, A. suzannae and K. plicatilis. 
TABLE 1 | Accession data of samples used in the museomic study of Aloidendron and related genera.

\begin{tabular}{|c|c|c|c|c|}
\hline Genus & $\begin{array}{l}\text { Herbarium }(\mathrm{H}) \text { or living }(\mathrm{L}) \\
\text { material }\end{array}$ & $\begin{array}{l}\text { Living collection and } \\
\text { accession number }{ }^{1}\end{array}$ & Collector's number & Distribution \\
\hline Aloe acutissima H. Perrier & $\mathrm{L}$ & 2010-1941, Kew & Grace 252 & Madagascar \\
\hline Aloe arborescens Mill. & $\mathrm{L}$ & P2012-5002, Copenhagen & Grace 195 & South Africa, Lesotho \\
\hline Aloe broomii Schönland & $\mathrm{L}$ & P2012-5005, Copenhagen & Grace 196 & South Africa \\
\hline Aloe camperi Schweinfurth. & $\mathrm{L}$ & 1973-13456, Kew & Grace 254 & Eritrea, Ethiopia \\
\hline Aloe castellorum J.R.I. Wood & $\mathrm{L}$ & 1981-2893, Kew & Grace 255 & Saudi Arabia, Yemen \\
\hline Aloe elegans Tod. & $\mathrm{L}$ & 1984-171, Kew & Grace 258 & Eritrea, Ethiopia \\
\hline Aloe gariepensis Pillans & $\mathrm{L}$ & - & Grace 275 & Namibia, South Africa \\
\hline Aloe greatheadii Schönland & $L$ & - & Grace 58 & $\begin{array}{l}\text { South Africa, Eswatini, } \\
\text { Zimbabwe, Mozambique, } \\
\text { Malawi, Botswana, Democratic } \\
\text { Republic of Congo }\end{array}$ \\
\hline Aloe officinalis Forssk. & $\mathrm{L}$ & 1975-4505, Kew & Grace 262 & Saudi Arabia, Yemen \\
\hline Aloe thraskii Baker & $\mathrm{L}$ & P2012-5030, Copenhagen & Grace 216 & South Africa \\
\hline $\begin{array}{l}\text { Aloestrela suzannae (Decary) } \\
\text { Molteno \& Gideon F.Sm }\end{array}$ & $L$ & 2012-675, Kew & Grace 272 & Madagascar \\
\hline $\begin{array}{l}\text { A. suzannae (Decary) Molteno \& } \\
\text { Gideon F.Sm }\end{array}$ & $\mathrm{H}$ & - & Decary 2913 (type) & Madagascar \\
\hline $\begin{array}{l}\text { Aloidendron barberae (Dyer) Klopper } \\
\text { \& Gideon F.Sm. }\end{array}$ & $\mathrm{H}$ & - & Unknown (type) & $\begin{array}{l}\text { South Africa, Mozambique, } \\
\text { Eswatini }\end{array}$ \\
\hline $\begin{array}{l}\text { A. barberae (Dyer) Klopper \& Gideon } \\
\text { F.Sm. }\end{array}$ & $L$ & 1947-29913, Kew & Grace 292 & $\begin{array}{l}\text { South Africa, Mozambique, } \\
\text { Eswatini }\end{array}$ \\
\hline $\begin{array}{l}\text { A. barberae (Dyer) Klopper \& Gideon } \\
\text { F.Sm. }\end{array}$ & $L$ & 1947-29913, Kew & Grace 292 & $\begin{array}{l}\text { South Africa, Mozambique, } \\
\text { Eswatini }\end{array}$ \\
\hline $\begin{array}{l}\text { Aloidendron dichotomum (Masson) } \\
\text { Klopper \& Gideon F.Sm. }\end{array}$ & $\mathrm{L}$ & 2015-832, Kew & Grace 289 & Namibia, South Africa \\
\hline $\begin{array}{l}\text { A. dichotomum (Masson) Klopper \& } \\
\text { Gideon F.Sm. }\end{array}$ & $\mathrm{H}$ & - & Reynolds 5400 & Namibia, South Africa \\
\hline $\begin{array}{l}\text { Aloidendron eminens (Reynolds } \\
\text { \& P.R.O. Bally) Klopper \& Gideon } \\
\text { F.Sm. }\end{array}$ & $\mathrm{L}$ & 1981-895, Kew & Grace 296 & Somalia \\
\hline $\begin{array}{l}\text { A. eminens (Reynolds \& P.R.O. Bally) } \\
\text { Klopper \& Gideon F.Sm. }\end{array}$ & $\mathrm{H}$ & - & Reynolds 8435 (type) & Somalia \\
\hline $\begin{array}{l}\text { Aloidendron pillansii (L. Guthrie) } \\
\text { Klopper \& Gideon F.Sm. }\end{array}$ & $L$ & SSZ 993355/6, SSZ & - & Namibia, South Africa \\
\hline $\begin{array}{l}\text { A. pillansii (L. Guthrie) Klopper \& } \\
\text { Gideon F.Sm. }\end{array}$ & $\mathrm{H}$ & - & Pillans 5012 (type) & Namibia, South Africa \\
\hline $\begin{array}{l}\text { Aloidendron ramosissimum (Pillans) } \\
\text { Klopper \& Gideon F.Sm. }\end{array}$ & $\mathrm{H}$ & - & Reynolds 2547 (type) & Namibia, South Africa \\
\hline $\begin{array}{l}\text { Aloidendron sabaeum (Schweinf.) } \\
\text { Boatwr. \& J.C. Manning }\end{array}$ & $\mathrm{L}$ & - & Van Wyk 14198 & Saudi Arabia, Yemen \\
\hline $\begin{array}{l}\text { A. sabaeum (Schweinf.) Boatwr. \& } \\
\text { J.C. Manning }\end{array}$ & $\mathrm{H}$ & - & Schweinfurthii 941 (type) & Saudi Arabia, Yemen \\
\hline $\begin{array}{l}\text { A. sabaeum (Schweinf.) Boatwr. \& } \\
\text { J.C. Manning }\end{array}$ & $\mathrm{L}$ & 1973-2559, Kew & Grace 299 & Saudi Arabia, Yemen \\
\hline Bulbine frutescens (L.) Willd. & $\mathrm{L}$ & 1973-3211, Kew & Grace 260 & South Africa \\
\hline
\end{tabular}

${ }^{1}$ Copenhagen, Copenhagen Botanic Garden, Denmark; Kew, Royal Botanic Gardens, Kew, United Kingdom; SSZ, Sukkulenten-Sammlung Zurich, Switzerland.

A genome skimming approach was used, in which genomic DNA is sequenced sufficiently to retrieve genomic regions present in high copy numbers, notably the plastid genome (Twyford and Ness, 2017; Weitemier et al., 2014). The DNA extracted from the living material was sheared in a Covaris Focused-ultrasonicator M220 into Covaris microTUBE AFA Fiber Pre-Slit Snap-Cap tubes with the following parameters: peak power 50.0 , duty factor 20 , cycles/burst 200 and treatment time $60 \mathrm{~s}$, to achieve an average DNA fragment length of 500 bp. In contrast, the DNA from the herbarium material was already degraded $(<300 \mathrm{bp})$ and therefore not sheared. The paired-end DNA libraries were prepared using the NEBNext Ultra II Library prep kit for Illumina (New England Biolabs,
MA) with insert sizes of $\sim 200$ bp for herbarium samples (highly fragmented and degraded DNA) and $~ 500 \mathrm{bp}$ for fresh silica-dried samples (high molecular weight and intact DNA). Importantly, a 10-fold adaptor dilution was used for the herbarium samples to avoid the formation of adaptor dimers during the library preparation. Library quality (concentration and insert size) was assessed with a Quantus fluorometer (Invitrogen, UK) and an Agilent 4200 TapeStation (Stockport, UK). Sequencing was performed on an Illumina MiSeq platform (Illumina, UK) to generate at least two million 150-bp-long paired-end reads for the herbarium samples and at least 5.7 million 250-bp-long paired-end reads for the silica-dried samples. 


\section{Data Cleaning, Plastome Assembly and Annotation}

Adaptors were removed and low-quality sequences trimmed using Trimmomatic 0.310 with the parameters MAXINFO:40:0.85 HEADCROP:1 MINLEN:36. The reads of the A. pillansii AT12 sample were assembled using the Fast-Plast (https:/github.com/ mrmckain/Fast-Plast) (McKain and Wilson, 2019) pipeline, which yielded one plastome contig. The circularity and integrity of the contig were checked by mapping the reads back to it using Geneious R8 (https://www.geneious.com). The plastome annotation was performed with GeSeq (Tillich et al., 2017), using the published plastome of Agave attenuata (NC_032696.1) (McKain et al., 2016) as a reference. The annotations were then inspected in Geneious R8 (https://www.geneious.com) and edited manually if necessary. The annotated plastid genome sequence of A. pillansii was deposited in GenBank (MN276325). The plastome map was drawn with OGDraw v.1.2 (Lohse et al., 2007).

\section{Phylogenetic Analysis}

The annotated plastome of $A$. pillansii was split into 91 coding (exons) and 113 non-coding (introns and intergenic spacers) regions, which were combined in a coding reference file and a non-coding reference file, respectively. The nuclear ribosomal ITS1_58S_ITS2 region of $A$. pillansii was added to the noncoding reference file. Each reference file was then used to recover homologous regions in all other samples (Table 1) using the pipeline HybPiper v.1.2 (Johnson et al., 2016). The pipeline mapped the clean reads of each sample against each reference locus using BWA (Li and Durbin, 2009), separately assembled the reads corresponding to each locus using SPAdes (v.3.11.1) (Bankevich et al., 2012), and, for each locus, combined the homologous regions found in all samples in a locus matrix. All 205 plastid and nuclear locus matrices were individually aligned using MAFFT 7 (Katoh and Standley, 2013) and inspected in Geneious R8 (Supplementary File S1). The internal transcribed spacer (ITS) matrix was analysed separately. Plastid coding and non-coding loci were concatenated into one plastid matrix of 148,678 nucleotide sites. A second plastid matrix was then obtained by removing from the first matrix all nucleotide sites with more than $75 \%$ gaps and five taxa that had a high proportion of missing data (Aloe arborescens A8, Aloe broomii A13, Aloe thraskii A83, A. barberae A10 and A. sabaeum AT3; see Table 1 and Results). The ITS alignment, consisting of 733 nucleotide sites, was analysed separately to allow the detection of nucleocytoplasmic conflicts.

The concatenated plastid matrix and the ITS matrix were each submitted to maximum-likelihood phylogenetic analysis using RAxML 8.2.9 (Stamatakis, 2014) via the CIPRES Science Gateway (Miller et al., 2010), with a GTRGAMMA evolutionary model specified. The plastid matrix was analysed as two partitions corresponding to the coding and non-coding regions. Node supports were estimated using a rapid bootstrap analysis with 1,000 replicates. All trees were rooted using B. frutescens as the outgroup, using the tree rooting function pxrr implemented in the phyx tool (Brown et al., 2017).

\section{RESULTS}

The museomics approach sampling preserved herbarium samples and living plants in curated botanical collections yielded 205 loci for 26 samples representing six species of Aloidendron, 10 of Aloe, A. suzannae and the outgroup B. frutescens (Table 1). We sequenced the type specimens of five out of seven species of Aloidendron, the exceptions being A. dichotomum and $A$. tongaensis. However, we did include a specimen of A. dichotomum collected in 1949 by G.W. Reynolds, which he described as "typical" (Reynolds, 1950: 490). The oldest among the samples used in this study was a herbarium specimen prepared in approximately 1874 at the Royal Botanic Gardens, Kew, from a cutting of $A$. barberae, sent from Kwa-Zulu-Natal in South Africa. Another historic sample was the type specimen of A. sabaeum, collected in February 1889 by George Schweinfurth. Other herbarium specimens sampled were all collected in the 20th century (Table 1). Despite optimisations, a modern sample of A. tongaensis (Van Jaarsveld, 2010), a species described in 2010 , could not be successfully sequenced.

The assembled plastome of $A$. pillansii was 154,094 bp long with a large single-copy (LSC) region of 84,002 bp and a short single-copy (SSC) region of 16,952 bp separated by two inverted repeats (IRs) of 26,570 bp (Figure 2). The LSC-IR $\mathrm{B}_{\mathrm{B}}$ boundary is located between the rpl22 and rpl19 ribosomal protein genes, and the LSC-IR $\mathrm{I}_{\mathrm{A}}$ boundary between rpl19 and psbA, while the SSC-IR $\mathrm{I}_{\mathrm{A}}$ and $\mathrm{SSC}-\mathrm{IR}_{\mathrm{B}}$ boundaries are within the $y c f 1$ gene.

Using the genes and intergenic regions of the plastome of A. pillansii as a reference allowed us to recover their homologous regions in most of the other samples (Figure 3). For each sample, the length of each recovered region was compared to the length of that region in A. pillansii (Table 2). For 17 samples, including the types of A. barberae, A. eminens, A. pillansii and A. ramosissimum, we could retrieve 181 to 203 of the 203 plastid loci at $>80 \%$ of their length (Figure 3). Three samples, including the type of A. suzannae and the historical specimen of A. dichotomum, had an intermediate recovery (127 to 160 loci), while the type of A. sabaeum and four other samples had only 1 to 68 plastid loci recovered at $>80 \%$ (Table 2 ). When considering loci spanning $>50 \%$ of the reference length, between 0 and 36 additional loci could be recovered, and the sample performance ranking was identical, with the same 17 samples performing very well (188203 loci), the same three intermediate samples (143-177 loci), and the same five samples with low recovery (22-81 loci; Table 2$)$. The recovery of the non-coding regions was somewhat less successful than that of the coding regions (Figure 3), with the percentage of loci recovered at $>80 \%$ of the reference length being almost always lower for non-coding loci than for coding loci, by up to 13 points in $A$. arborescens (Table 2). A notable exception was the low-performing $A$. barberae sample A10, for which $15.2 \%$ of the non-coding loci were recovered, against only $8 \%$ of the coding loci (Table 2). The ITS region could be recovered in all samples at $>98.5 \%$ of the reference length, except for the type of A. sabaeum, where it was not recovered, and the type of $A$. ramosissimum and the outgroup Bulbine, where only $41.4 \%$ and $64.3 \%$ of the reference region could be found, respectively (Figure 3; Table 2). 


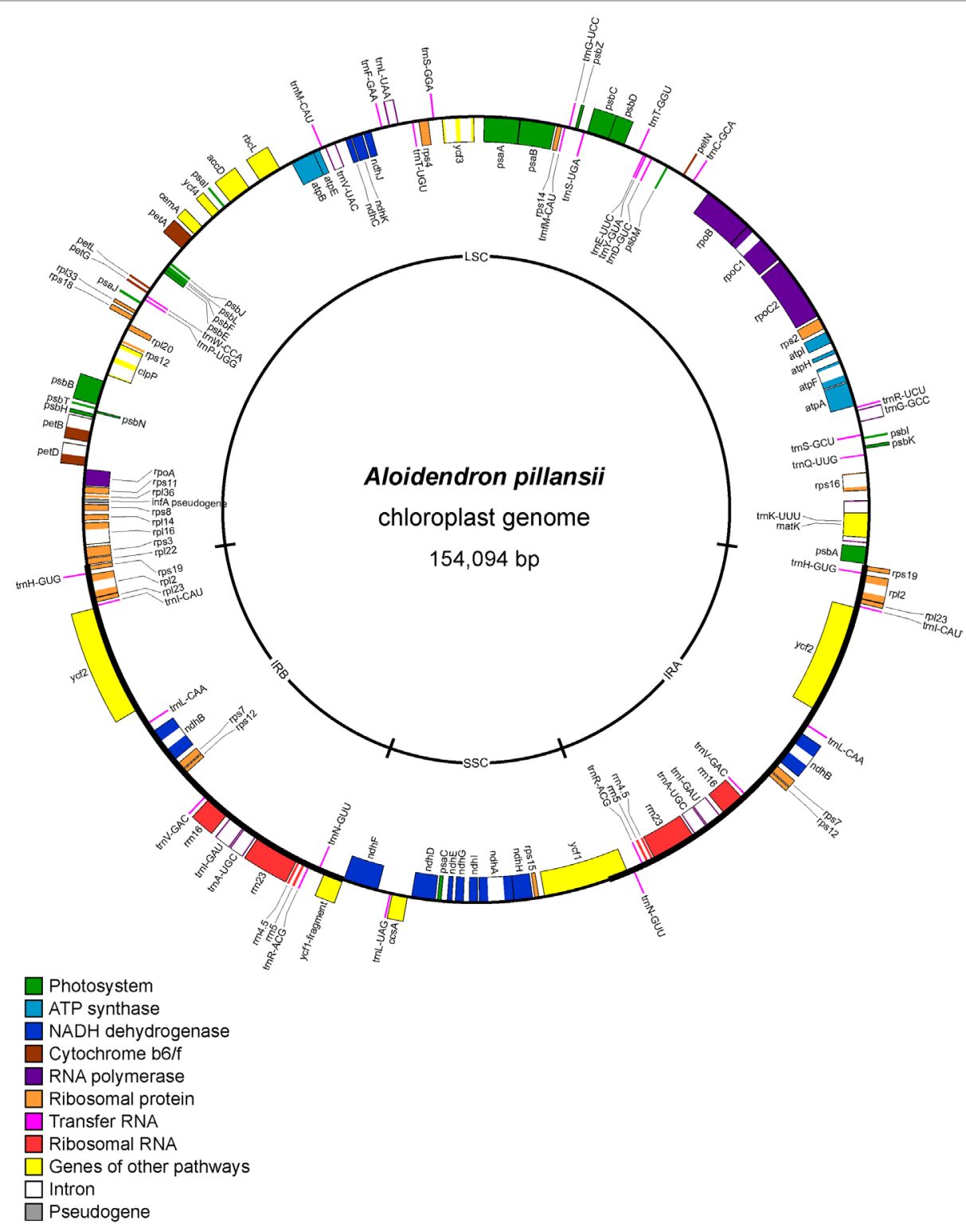

FIGURE 2 | Gene map of Aloidendron pillansii chloroplast genome (GenBank MN276325). Genes illustrated inside the circle are transcribed in a clockwise direction relative to the figure, and genes outside the circle are transcribed in an anticlockwise direction.

Maximum-likelihood trees were estimated from all plastid loci and ITS (Figure 4) and with gappy sites and sequences removed (Figure S1). The historical specimens and types always grouped with conspecific samples from fresh material (Figure 4), and long branches, possibly due to missing data (Darriba et al., 2016), did not affect the topology (Figure S1). A consensus of the plastid and ITS topologies focusing on the tree aloes with the geographical and ecological distribution of each species is shown in Figure 5. Both plastid and nuclear regions recovered two major well-supported clades, one consisting mainly of Aloes and the other comprising mostly Aloidendron species. However, neither of these genera was monophyletic (Figure 4), since the Aloe clade included A. sabaeum with $\mathrm{BP}=59$ (ITS) to $\mathrm{BP}=100$ (plastid) and the Aloidendron clade included $A$. suzannae with $\mathrm{BP}=83$ (ITS) to $\mathrm{BP}=100$ (plastid).
The focus of this study, Aloidendron, consisted of two subclades recovered in both the ITS and the plastid phylogenies: a southwestern African desert clade $(\mathrm{BP}=100)$ comprising the morphologically similar and sympatric desert species A. dichotomum, A. ramosissimum and A. pillansii and an eastern clade $(B P=83$ or 100$)$ comprising the narrowly endemic Somalian humid thicket species A. eminens and the Madagascar endemic arid thicket species A. suzannae. The southern African humid forest/thicket species $A$. barberae was recovered in the desert clade in the plastid tree $(B P=100)$, but in the eastern clade in the ITS tree, sister to A. suzannae (BP = 93; Figure 4). Among the species of the desert clade, the two samples of $A$. pillansii were not monophyletic, and although sample AT4 was recovered as sister to the other species in both 


\section{A}

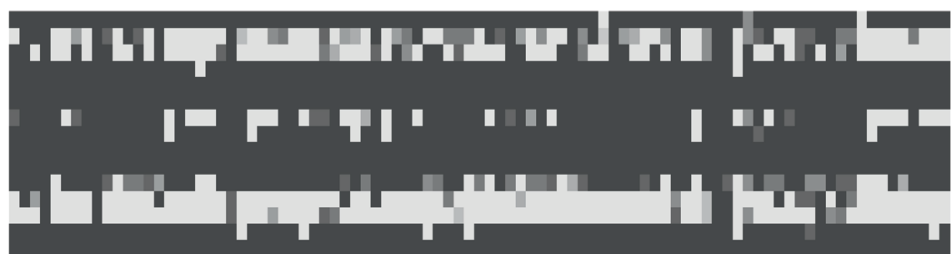
Aloe acutissima A252 Aloe arborescens $\mathrm{A}$
Aloe broomii A13 Aloe camperi A254
Aloe castellorum A2 Aloe castellorum A2
Aloe elegans A258 Aloe gariepensis A35
Aloe greatheadii A37 Aloe greatheadii A37
Aloe o o cinalis A262 Aloestrela suzannie A272 Aloestrela suzann Aloidendron barberae A10 Aloidendron barberae AT7

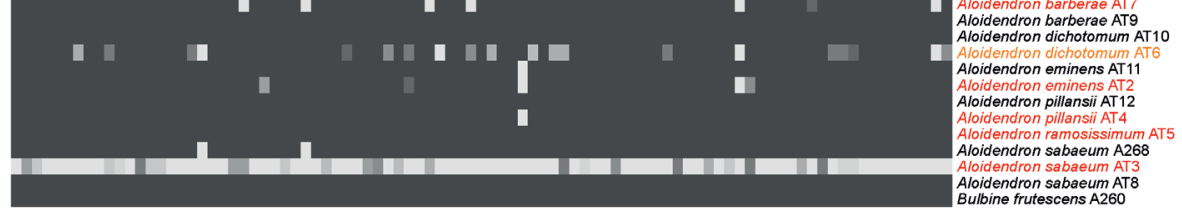
Aloidendron dichotomum ATr Aloidendron eminens AT2 Aloidendron pillansii AT 12 Aloidendron ramosissimum A Aloidendron sabaeum AT

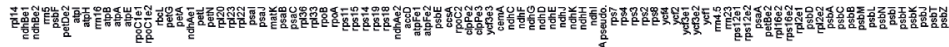

B

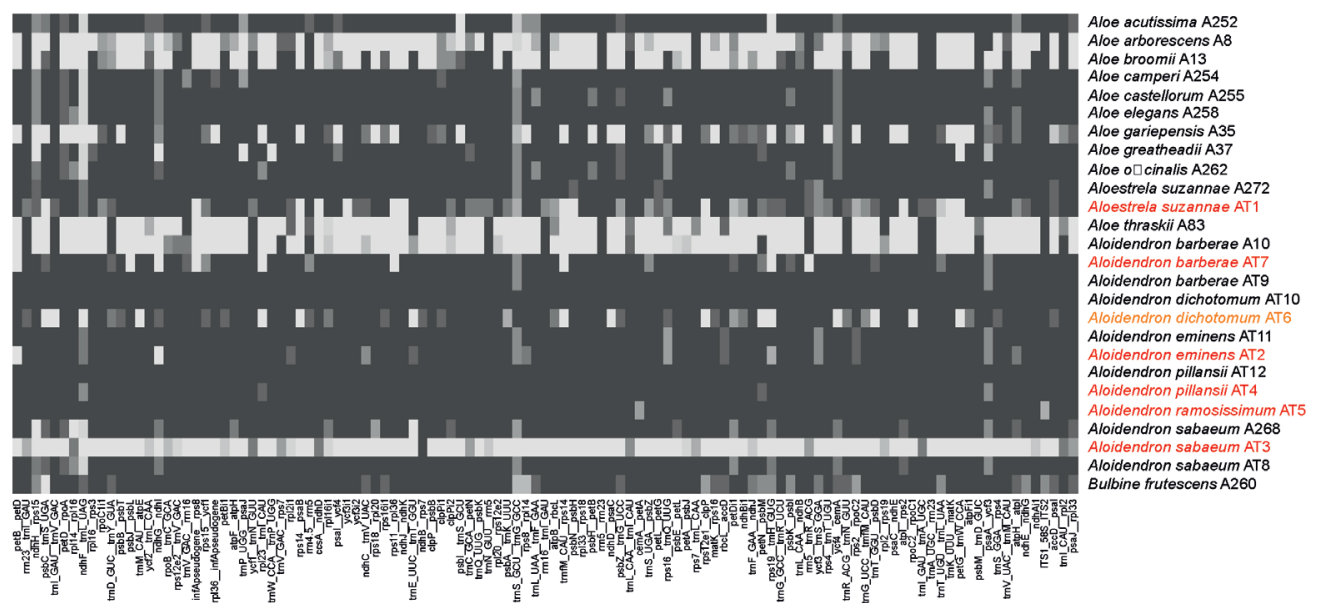

FIGURE 3 | Heatmaps showing gene recovery efficiency for (A) coding plastid loci and (B) non-coding plastid loci and the nuclear ribosomal internal transcribed spacer (ITS) region in 25 species of Asphodelaceae. Columns represent genes, and each row is one sample. Shading indicates the percentage of the reference locus length coverage. Samples retrieved from type or historical specimens are highlighted in red and orange, respectively.

trees, sample AT12 was either sister to A. ramosissimum $+A$. dichotomum in the ITS tree $(\mathrm{BP}=33)$ or sister to $A$. dichotomum in the plastid tree $(\mathrm{BP}=66)$. The relationships in the Aloe clade were similar in the ITS and plastid tree, except for three wellsupported (BP $\geq 70$ ) nucleocytoplasmic conflicts (Figure 4). Aloe officinalis and Aloe castellorum were recovered as sister species in the plastid tree, but in the ITS tree, they formed a grade around the clade comprising Aloe gariepensis, Aloe camperi, Aloe elegans and Aloe greatheadii. The latter species was not part of this clade in the plastid tree but instead was inferred to have diverged earlier. Finally, although A. sabaeum was nested in Aloe in both trees, its precise position varied from being sister to all sampled Aloes except $A$. arborescens in the ITS tree $(\mathrm{BP}=48)$ and being sister to A. officinalis + A. castellorum in the plastid tree $(\mathrm{BP}=67)$.

\section{DISCUSSION}

Museomic, or herbariomic, approaches based on preserved botanical collections can fill critical gaps in phylogenetic sampling, particularly when species are extinct in the wild (Silva et al., 2017) or taxonomically complex (Chomicki and
Renner, 2014). In this study, sequencing historic reference material, including the type specimens of five Aloidendron species, minimised risks of misidentification which may otherwise apply to slow-growing plants in cultivation, particularly when they flower infrequently. All species represented by both herbarium specimens and living plants were consistently recovered together in phylogenetic trees (Figures 4, 5), highlighting, in turn, the value of well-curated living collections in plant systematics. In recent years, the value of degraded and/or historic botanical specimens has been illustrated primarily in the context of crop domestication (e.g. the potato, Solanum tuberosum) (Gutaker et al., 2019). Although DNA extraction from herbarium specimens and the fragmentary nature of their DNA pose persistent challenges to sequencing, the sensitivity of high-throughput sequencing technologies now makes it possible to include herbarium samples in molecular systematic studies. Our herbariomic approach allowed for the recovery of many coding and noncoding plastid loci as well as the nuclear ITS region from most samples, including the historical ones. In addition, we showed that genome skimming can be successfully used to sequence plastid genomes in Asphodelaceae. The A. pillansii plastome 
TABLE 2 | Locus recovery in Aloidendron and related genera compared to the number and length of the reference loci. Samples from type and historic specimens are shown in red and orange, respectively and the reference in bold.

\begin{tabular}{|c|c|c|c|c|c|}
\hline Sample & $\begin{array}{l}\text { Total number of plastid } \\
\text { loci recovered at }>50 \%\end{array}$ & $\begin{array}{l}\text { Total number of plastid } \\
\text { loci recovered at }>80 \%\end{array}$ & $\begin{array}{l}\% \text { Plastid coding loci } \\
\text { recovered at } 80 \%\end{array}$ & $\begin{array}{l}\% \text { Plastid non-coding loci } \\
\text { recovered at } 80 \%\end{array}$ & $\begin{array}{l}\% \text { Reference ITS } \\
\text { length recovered }\end{array}$ \\
\hline Aloe acutissima A252 & 197 & 189 & 96.7 & 90.2 & 100 \\
\hline Aloe arborescens A8 & 77 & 45 & 29.7 & 16.1 & 100 \\
\hline Aloe broomii A13 & 81 & 68 & 34.1 & 33.0 & 100 \\
\hline Aloe camperi A254 & 200 & 192 & 97.8 & 92.0 & 98.5 \\
\hline Aloe castellorum A255 & 202 & 194 & 100.0 & 92.0 & 98.5 \\
\hline Aloe elegans A258 & 202 & 195 & 100.0 & 92.9 & 98.5 \\
\hline Aloe gariepensis A35 & 143 & 127 & 69.2 & 57.1 & 98.5 \\
\hline Aloe greatheadii A37 & 190 & 186 & 93.4 & 90.2 & 98.5 \\
\hline Aloe officinalis A262 & 202 & 193 & 100.0 & 91.1 & 98.5 \\
\hline Aloe thraskii A83 & 41 & 31 & 15.4 & 15.2 & 98.5 \\
\hline Aloestrela suzannae A272 & 203 & 199 & 100.0 & 96.4 & 100 \\
\hline A. suzannae AT1 & 170 & 134 & 65.9 & 66.1 & 100 \\
\hline Aloidendron barberae A10 & 35 & 25 & 8.8 & 15.2 & 100 \\
\hline A. barberae AT7 & 188 & 181 & 93.4 & 85.7 & 100 \\
\hline A. barberae AT9 & 203 & 201 & 100.0 & 98.2 & 100 \\
\hline Aloidendron dichotomum AT10 & 203 & 203 & 100.0 & 100.0 & 100 \\
\hline A. dichotomum AT6 & 177 & 160 & 80.2 & 77.7 & 100 \\
\hline Aloidendron eminens AT11 & 202 & 197 & 98.9 & 95.5 & 99.9 \\
\hline A. eminens AT2 & 198 & 188 & 95.6 & 90.2 & 100 \\
\hline Aloidendron pillansii AT12 & 203 & 203 & 100.0 & 100.0 & 100 \\
\hline A. pillansii AT4 & 202 & 200 & 98.9 & 98.2 & 100 \\
\hline Aloidendron ramosissimum AT5 & 203 & 202 & 100.0 & 99.1 & 41.4 \\
\hline Aloidendron sabaeum A268 & 197 & 188 & 97.8 & 88.4 & 100 \\
\hline A. sabaeum AT3 & 22 & 1 & 0.0 & 0.9 & 0 \\
\hline A. sabaeum AT8 & 202 & 194 & 100.0 & 92.0 & 100 \\
\hline Bulbine frutescens A260 & 200 & 190 & 100.0 & 88.4 & 64.3 \\
\hline
\end{tabular}

assembled for the study complies with the typical angiosperm chloroplast arrangement which is characterised by large and small single-copy regions separated by two $I R$ regions $\left(\mathrm{IR}_{\mathrm{A}}\right.$ and $\left(R_{B}\right)$ (Palmer, 1985). The loss of rpl32 from members of Asphodelaceae (Steele et al., 2012) was confirmed in this species (Figure 2).

The plastid and nuclear phylogenies inferred from our herbariomic data provide compelling insights into the taxonomy and speciation of tree aloes (Figure 4). Arborescent aloes conforming to Raunkier's succulent phanerophyte life form (Raunkier, 1934) were recently elevated to the genus rank in Aloidendron and Kumara (Grace et al., 2013). Kumara is a distinctive monophyletic Cape genus comprising the arborescent $K$. plicatilis and the short-stemmed shrub, Kumara haemanthifolia (Marloth \& A. Berger) Boatwr. \& J.C. Manning (Manning et al., 2014). Previously, all seven Aloidendron species were included in Aloe sections Dracaloe and Aloidendron, as circumscribed by Alwyn Berger (Berger, 1908) and Gilbert Reynolds (Reynolds, 1950). However, the phylogenetic placements that we recovered for A. sabaeum and $A$. suzannae question these two taxonomic treatments of tree aloes (Figure 4).

The phylogenetic placement of the Arabian species A. sabaeum in Aloe has nomenclatural implications (Smith et al., 2019). Aloe sabaea Schweinf. was transferred to Aloidendron (Manning et al., 2014) following Gilbert Reynolds' grouping (Reynolds, 1966) grouping of this species with the eastern tree aloes [A. eminens and Aloe bainesii
(= A. barberae)] on the basis of an erroneous record of its height of up to $9 \mathrm{~m}$, whereas in fact $A$. sabaea reaches only $3 \mathrm{~m}$ on maturity (Carter et al., 2011). The concept of Aloidendron sensu Grace et al. (2013) excluded A. sabaea on this basis and is supported by our study. In addition, the recognition of the Madagascar endemic A. suzannae (= Aloe suzannae L.) as a monotypic genus (Smith and Molteno, 2019) was not supported in this first effort to sequence it, given that it was recovered as sister to A. eminens within the Aloidendron clade. Finally, species boundaries in Aloidendron may also need to be reassessed, as suggested by the non-monophyly of the two accessions of $A$. pillansii included in our study. A more detailed analysis of phylogenomic and morphological trait data may help to resolve the taxonomic rank of potentially conspecific taxa in the southwestern desert clade. Hybridisation events or conflicting gene histories may require closer consideration. For instance, the conflicting positions of $A$. barberae and of some Aloe species between the nuclear and plastid trees (Figure 4) may be indicative of hybridisation followed by chloroplast capture or of incomplete lineage sorting. Expanded sampling and sequencing of additional nuclear genes could help in tackling these challenges. Our demonstration of highthroughput sequencing applied to Asphodelaceae herbarium material opens opportunities for a phylogenomic study of the family to underpin the necessary taxonomic revision.

Our phylogeny also provides a new context in which to assess the biogeography of tree aloes and the evolution of their arborescent habit and ecological preferences (Figure 5). 


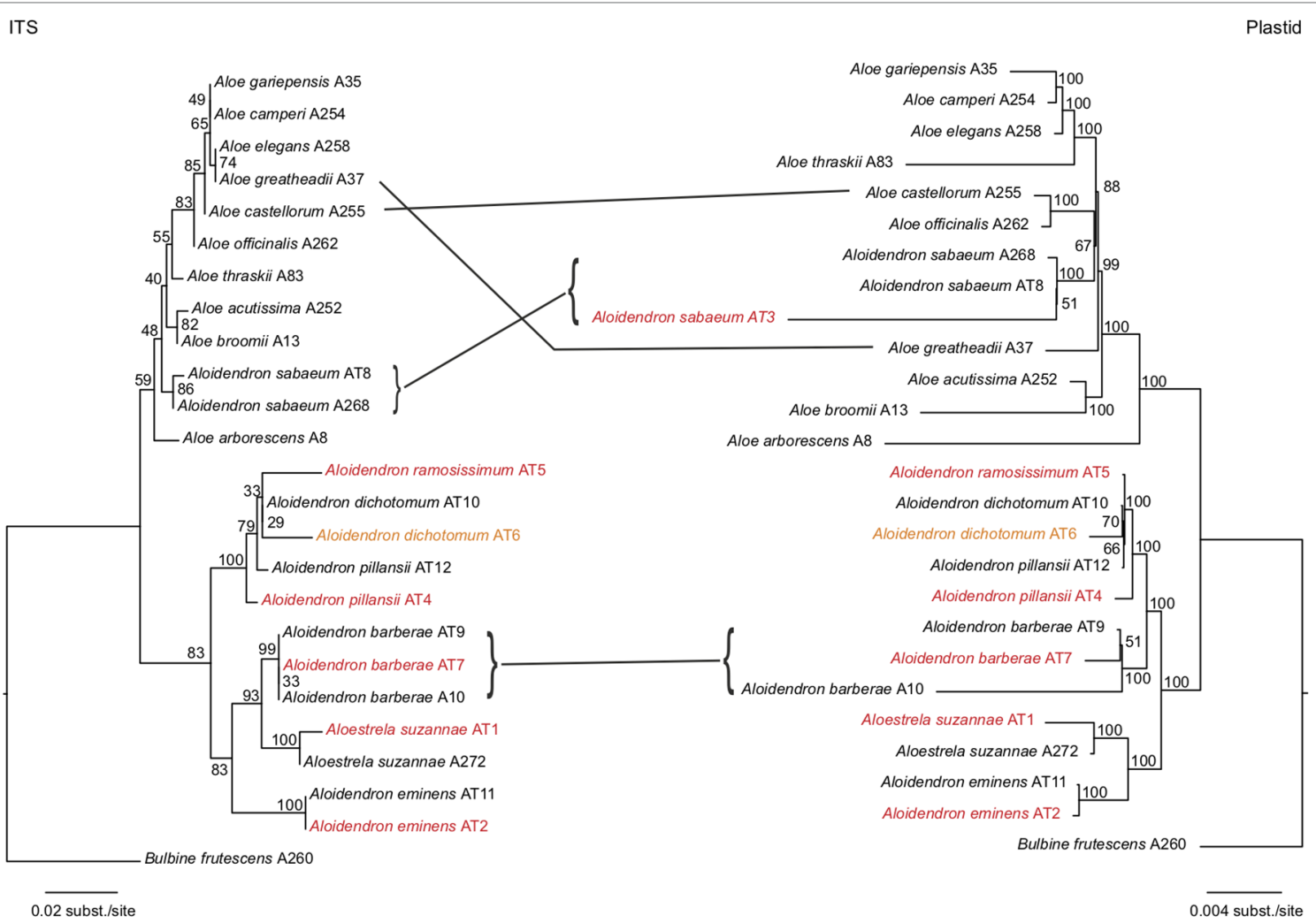

FIGURE 4 | Maximum-likelihood trees estimated from 204 plastid loci and internal transcribed spacer (ITS), recovered for 25 samples representing Aloidendron, Aloestrela and Aloe with node supports expressed as bootstrap percentages. Samples retrieved from type or historical specimens are highlighted in red and orange, respectively.

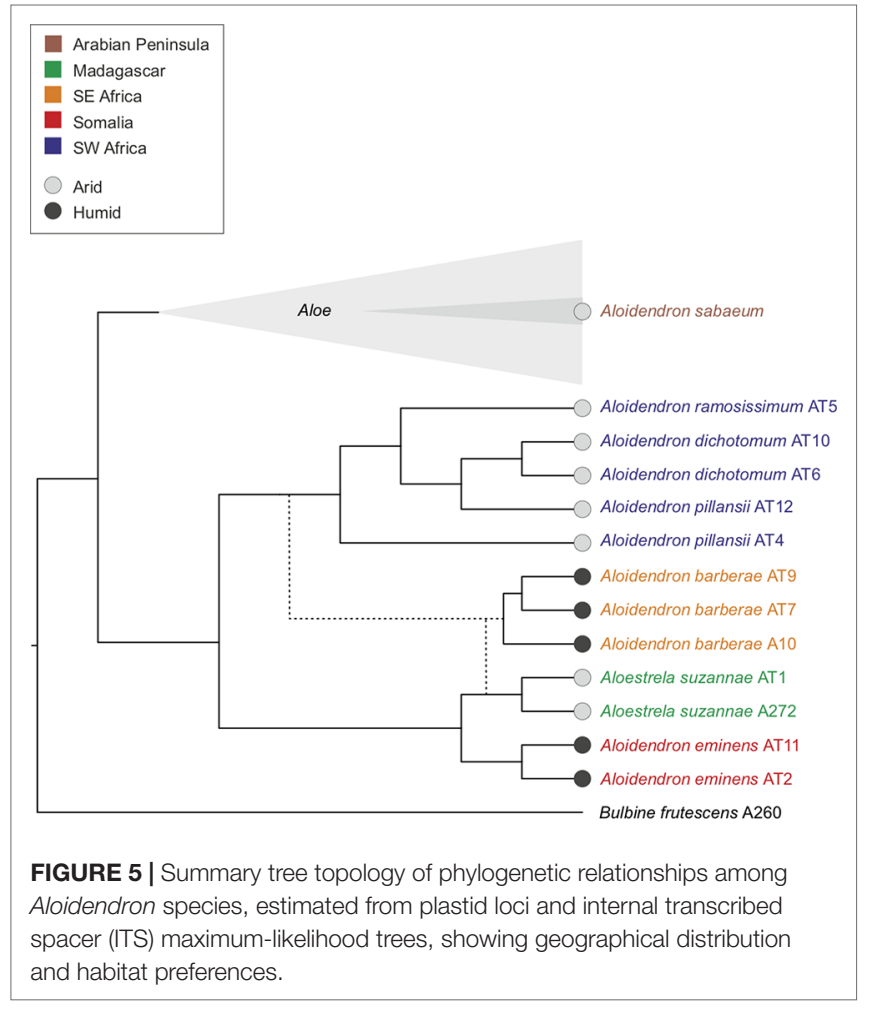

The four southwestern African desert Aloidendron species share short, ventricose flowers and are pollinated by shortbilled birds, whereas the eastern humid forest species $A$. tongaensis and A. eminens have longer, curved flowers in pendant racemes and are pollinated by sunbirds (Botes et al., 2008; Van Jaarsveld and Judd, 2015). This led to an interpretation of the desert and humid forest groups as two distinct evolutionary lineages (Van Jaarsveld and Judd, 2015), which was not, however, supported by our study. Instead, the two clades in Aloidendron correspond to the two geographical regions in which the genus is represented: southern Africa and east Africa/Madagascar. The geographical trend observed in our phylogeny of Aloidendron has also been observed in the related genus Aloe (Grace et al., 2015).

The range disjunction of Aloidendron between southern Africa and the Horn of Africa (Figures 1 and 5) conforms to the Rand Flora pattern, in which related taxa that were once linked by an arid corridor between southern Africa and north-east Africa are now widely separated (Sanmartin et al., 2010; Pokorny et al., 2015). Intense aridification during the Miocene and Pliocene was the major driver of the disjunct distributions shared by 12 angiosperm families in the African flora (Sanmartin et al., 2010; Pokorny et al., 2015), and these conditions have been linked to successive radiations of Aloe in Africa (Grace et al., 2015). One hypothesis to explain the 
geographical pattern found in this study, therefore, is that extant Aloidendron are the relics of a previously widespread group of arborescent aloes that were linked by the arid corridor reaching from south-west Africa to the eastern seaboard of Africa. However, a more plausible scenario is that Aloidendron followed the same pattern as Aloe (Grace et al., 2015), with early-diverging tree aloes undergoing at least one dispersal event from southern Africa northwards to reach the Horn of Africa and Madagascar, at the distal regions of the range for tree aloes. It is also possible that the extant diversity of Aloidendron in southern Africa reflects both extinctions in the desert regions and diversification in the East African range. The phylogenetic proximity of $A$. suzannae to A. eminens is therefore explained by a common ancestor on the African continent, from ancient radiations of the arborescent habit from a southern African origin. A. sabaeum (= Aloe sabaea), in contrast, likely evolved from the radiation of Aloe on the Arabian Peninsula within the last 5 million years (Grace et al., 2015) (Figures 4 and 5). The water-storing leaves of arborescent succulent phanerophytes may have been an important adaptation that allowed aloes to migrate northwards during Miocene drought conditions from southern Africa to the Horn of Africa, eastern Indian Ocean Islands and, finally, the Arabian Peninsula (Grace et al., 2015; Dee et al., 2018). Further biogeographic studies of the aloes of Madagascar and other Indian Ocean islands will likely determine whether the evolutionary history of Aloe and related genera is similar to that of continental Africa (Grace et al., 2015; Dee et al., 2018), with earlier radiations of arborescent lineages followed by at least one rapid radiation of short-stemmed chamerophyte taxa.

Our findings emphasise the value of herbarium specimens in monographing a taxonomically complex, slow-growing, and diverse succulent group. Further work to expand the phylogenetic sampling of a wider variety of life forms among Asphodelaceae subf. Alooideae will add insights into their evolutionary history.

\section{REFERENCES}

Bankevich, A., Nurk, S., Antipov, D., Gurevich, A. A., Dvorkin, M., and Kulikov, A. S. (2012). SPAdes: a new genome assembly algorithm and its applications to single-cell sequencing. J. Comput. Biol. 19, 455-477. doi: $10.1089 / \mathrm{cmb} .2012 .0021$

Berger, A. (1908). "Liliaceae-Asphodeloideae-Aloineae," in Das Pflanzenreich (Leipzig: Engelmann).

Botes, L., Van der Westhuizen, F. H., and Loots, D. T. (2008). Phytochemical contents and antioxidant capacities of two Aloe greatheadii var. davyana extracts. Molecules 13, 2169-2180. doi: 10.3390/molecules13092169

Brown, J. W., Walker, J. F., and Smith, S. A. (2017). Phyx: phylogenetic tools for Unix. Bioinformatics 33, 1886-1888. doi: 10.1093/bioinformatics/btx063

Carter, S., Lavranos, J. J., Walker, C., and Newton, L. E. (2011). Aloes: the definitive guide. Kew: Royal Botanic Gardens.

Chomicki, G., and Renner, S. S. (2014). Rapid report watermelon origin solved with molecular phylogenetics including Linnaean material: another example of museomics. New Phytol. 205, 526-532. doi: 10.1111/nph.13163

Darriba, D., Weiß, M., and Stamatakis, A. (2016). Prediction of missing sequences and branch lengths in phylogenomic data. Bioinformatics 32, 1331-1337. doi: 10.1093/bioinformatics/btv768

\section{DATA AVAILABILITY STATEMENT}

The Aloidendron pillansii chloroplast, complete genome has been deposited in the GenBank under accession number MN276325.

\section{AUTHOR CONTRIBUTIONS}

OG designed the study. PM, RD and OG conducted experimental work. SB, PM and OG analyzed and interpreted the results. OG, PM and $\mathrm{SB}$ prepared the manuscript which was agreed on by all authors.

\section{FUNDING}

This study was supported by a grant to OG from the Systematics Association Research Fund.

\section{ACKNOWLEDGMENTS}

We are grateful to Paul Rees and Harry Smith at the Royal Botanic Gardens, Kew, for assistance in sampling herbarium and living collections. We also thank Prof. Braam van Wyk (University of Pretoria), Dr Urs Eggli (Sukkulenten-Sammlung Zurich) and Martin Aarseth Hansen (Copenhagen Botanic Garden) for plant material, and Solofo Rakotoarisoa (Royal Botanic Gardens, Kew) for a photograph of Aloestrela suzannae.

\section{SUPPLEMENTARY MATERIAL}

The Supplementary Material for this article can be found online at: https://www.frontiersin.org/articles/10.3389/fpls.2019.01227/ full\#supplementary-material

SUPPLEMENTARY FILE S1 | Alignments of ITS and plastid sequence data of Aloidendron and related genera analysed in this study.

SUPPLEMENTARY FIGURE 1 | Maximum likelihood tree estimated from plastid loci with $<75 \%$ gaps recovered for 20 samples representing 14 species of Aloidendron, Aloestrela and Aloe with node supports expressed as bootstrap percentages.

Dee, R., Malakasi, P., Rakotoarisoa, S. E., and Grace, O. M. (2018). A phylogenetic analysis of the genus Aloe (Asphodelaceae) in Madagascar and the Mascarene Islands. Bot. J. Linn. Soc. 187, 428-440. doi: 10.1093/botlinnean/boy026

Doyle, J. J., and Doyle, J. L. (1987). A rapid DNA isolation procedure for small quantities of fresh leaf tissue. Phytochem. Bull. 19, 11-15.

Foden, W., Midgley, G. F., Hughes, G., Bond, W. J., Thuiller, W., Hoffman, M. T., et al. (2007). A changing climate is eroding the geographical range of the Namib Desert tree Aloe through population declines and dispersal lags. Divers. Distrib. 13, 645-653. doi: 10.1111/j.1472-4642.2007.00391.x

Goodwin, Z. A., Harris, D. J., Filer, D., Wood, J. R. I., and Scotland, R. W. (2015). Widespread mistaken identity in tropical plant collections. CURBIO 25, R1066-R1067. doi: 10.1016/j.cub.2015.10.002

Grace, O. M., Buerki, S., Symonds, M. R., Forest, F., van Wyk, A. E., Smith, G. F., et al. (2015). Evolutionary history and leaf succulence as explanations for medicinal use in aloes and the global popularity of Aloe vera. BMC Evol. Biol. 15, 1-12. doi: 10.1186/s12862-015-0291-7

Grace, O. M., Klopper, R. R., Smith, G. F., Crouch, N. R., Figueiredo, E., Ronsted, N., et al. (2013). A revised generic classification of Aloe (Xanthorrhoeaceae subfam. Asphodeloideae). Phytotaxa 76, 7-14. doi: 10.11646/phytotaxa.76.1.2

Gutaker, R. M., Clemens, L. W., Ellis, D., Anglin, N. L., Knapp, S., FernándezAlonso, J. L., et al. (2019). The origins and adaptation of European potatoes 
reconstructed from historical genomes. Nat. Ecol. Evol. 3, 1093-1101. doi: 10.1038/s41559-019-0921-3

Jack, S. L., Hoffman, M. T., Rohde, R. F., and Durbach, I. (2016). Climate change sentinel or false prophet? The case of Aloe dichotoma.. Divers. Distrib. 22, 745757. doi: $10.1111 /$ ddi. 12438

Johnson, M. G., Gardner, E. M., Liu, Y., Medina, R., Goffinet, B., Shaw, A. J., et al. (2016). HybPiper: extracting coding sequence and introns for phylogenetics from high-throughput sequencing reads using target enrichment. 2Applications Plant Sci. 4, 1600016. doi: 10.3732/apps.1600016

Katoh, K., and Standley, D. M. (2013). MAFFT multiple sequence alignment software version 7: improvements in performance and usability. Mol. Biol. Evol. 30, 772-780. doi: 10.1093/molbev/mst010

Li, H., and Durbin, R. (2009). Fast and accurate short read alignment with Burrows-Wheeler transform. Bioinformatics 25, 1754-1760. doi: 10.1093/ bioinformatics/btp324

Lohse, M., Drechsel, O., and Bock, R. (2007). OrganellarGenomeDRAW (OGDRAW) - a tool for the easy generation of high-quality custom graphical maps of plastid and mitochondrial genomes. Curr. Genet. 52, 267-274. doi: 10.1007/s00294-007-0161-y

Manning, J. C., Boatwright, J. S., Daru, B. H., Maurin, O., and Van der Bank, M. (2014). A molecular phylogeny and generic classification of Asphodelaceae subfamily Alooideae: a final resolution of the prickly issue of polyphyly in the alooids? Syst. Bot. 39, 55-74. doi: 10.1600/036364414X678044

McKain, M. R., and Wilson, M. (2019). Fast-Plast: rapid de novo assembly and finishing for whole chloroplast genomes. https://github.com/mrmckain.

McKain, M. R., McNeal, J. R., Kellar, P. R., Eguiarte, L. E., Pires, J. C., and LeebensMack, J. H. (2016). Timing of rapid diversification and convergent origins of active pollination within Agavoideae (Asparagaceae). Am. J. Bot. 103, 17171729. doi: $10.3732 /$ ajb. 1600198

Miller, M. A., Pfeiffer, W., and Schwartz, T. (2010). Creating the CIPRES Science Gateway for inference of large phylogenetic trees. 2010 Gatew. Comput. Environ. Work. GCE 2010 1-8. doi: 10.1109/GCE.2010.5676129

Palmer, J. (1985). Comparative organization of chloroplast genomes. Annu. Rev. Genet. 19, 325-354. doi: 10.1146/annurev.ge.19.120185.001545

Pokorny, L., Riina, R., Mairal, M., Meseguer, A. S., Culshaw, V., Cendoya, J., et al. (2015). Living on the edge: timing of Rand Flora disjunctions congruent with ongoing aridification in Africa. Front. Genet. 6, 1-15. doi: 10.3389/ fgene.2015.00154

Raunkier, C. (1934). The life forms of plants and their bearings on geography. Oxford: Oxford University Press.

Reynolds, G. (1950). The aloes of Southern Africa. Johannesburg: Aloes Book Fund. Reynolds, G. W. (1966). The aloes of tropical Africa and Madagascar. Mbabane: Aloes Book Fund.

Sanmartin, I., Anderson, C. L., Alarcon, M., Ronquist, F., and Aldasoro, J. J. (2010). Bayesian island biogeography in a continental setting: the Rand Flora case. Biol. Lett. 24. doi: 10.1098/rsbl.2010.0095
Silva, C., Besnard, G., Piot, A., Razanatsoa, J., Oliveira, R. P., and Vorontsova, M. S. (2017). Museomics resolve the systematics of an endangered grass lineage endemic to Madagascar. Ann. Bot. 119, 339-351. doi: 10.1093/aob/mcw208

Smith, G. F., and Molteno, S. (2019). Aloestrela Molteno \& Gideon F. Sm. (Asphodelaceae: Alooideae), a new alooid genus with A. suzannae (Decary) Molteno \& Gideon F.Sm. as the only species. Bradleya 37, 3-7. doi: 10.25223/brad.n37.2019.a2

Smith, G. F., Klopper, R. R., and Grace, O. M. (2019) Aloidendron (Asphodelaceae subfam. Alooideae) consists of six species, not seven: Aloe sabaea is a true aloe. Phytotaxa 416, 089-090. doi: 10.11646/phytotaxa.416.1.11

Stamatakis, A. (2014). RAxML version 8: a tool for phylogenetic analysis and post-analysis of large phylogenies. Bioinformatics 30, 1312-1313. doi: 10.1093/ bioinformatics/btu033

Steele, P. R., Hertweck, K., Mayfield, D., McKain, M. R., Leebens-Mack, J., and Pires, J. C. (2012). Quality and quantity of data recovered from massively parallel sequencing: examples in Asparagales and Poales. Am. J. Bot. 99, 330348. doi: 10.3732/ajb.1100491

Tillich, M., Lehwark, P., Pellizzer, T., Ulbricht-Jones, E., Fischer, A., Bock, R., et al. (2017). GeSeq-versatile and accurate annotation of organelle genomes. Nucleic Acids Res. 45, W6-W11. doi: 10.1093/nar/gkx391

Twyford, A. D., and Ness, R. W. (2017). Strategies for complete plastid genome sequencing. Mol. Ecol. Resour. 17, 858-868. doi: 10.1111/1755-0998.12626

Van Der Linde, J. A., Roux, J., Wingfield, M. J., and Six, D. L. (2012). Die-off of giant Euphorbia trees in South Africa: symptoms and relationships to climate. South African J. Bot. 83, 172-185. doi: 10.1016/j.sajb.2012.08.008

Van Jaarsveld, E. J. (2010). Aloe tongaensis, a new species from Tongaland, KwaZulu-Natal (South Africa), and a new sectional arrangement of the tree aloes. Aloe 47, 64-71.

Van Jaarsveld, E. J., and Judd, E. (2015). Tree aloes of Africa. Tygervalley, South Africa: Penrock Publications.

van Wyk, A., and Smith, G. (2001). Regions of floristic endemism in Southern Africa. Hatfield: Umdaus.

Weitemier, K., Straub, S. C. K., Cronn, R. C., Fishbein, M., Schmickl, R., McDonnell, A., et al. (2014). Hyb-Seq: combining target enrichment and genome skimming for plant phylogenomics. Plant Sci. 2, 1400042. doi: 10.3732/apps.1400042

Conflict of Interest: The authors declare that the research was conducted in the absence of any commercial or financial relationships that could be construed as a potential conflict of interest.

Copyright $\odot 2019$ Malakasi, Bellot, Dee and Grace. This is an open-access article distributed under the terms of the Creative Commons Attribution License (CC $B Y)$. The use, distribution or reproduction in other forums is permitted, provided the original author(s) and the copyright owner(s) are credited and that the original publication in this journal is cited, in accordance with accepted academic practice. No use, distribution or reproduction is permitted which does not comply with these terms. 